\title{
Investigating the effect of adjusted DuPont ratio and its components on investor's decisions in short and long term
}

\author{
Majid Zanjirdar $^{\mathrm{a}}$, Parvaneh Khaleghi Kasbi ${ }^{\mathbf{b}^{*}}$ and Zahra Madahi ${ }^{\mathrm{b}}$
}

${ }^{a}$ Assistant Professor of Accounting, Arak Branch, Islamic Azad University (IAU), Arak, Iran

${ }^{b}$ Master of Science in Accounting, Markazi Science and Reserch Branch, Islamic Azad University (IAU), Arak, Iran

\section{H R O N I C L E A B S T R A C T}

Article history:

Received June 28, 2013

Received in revised format

19 October 2013

Accepted 2 January 2014

Available online

January 42014

Keywords:

Adjusted DuPont analysis

Return on net operating assets

Profit margin

Asset turnover operating

Herding behavior

Finance behavioral

\begin{abstract}
This paper investigates the effect of adjusted DuPont ratio and its components on investors' decisions in short and long term. The primary objective of this study is to find the effect of adjusted DuPont ratio and its components on herding behavior of investors in one and several year period. Hence, 85 corporations as the member of Tehran stock exchange over the period 2006-2011 are selected. In order to recognize the herding, by market index consideration, the herded $\beta$ and in order to hypothesis validity SPSS software and multivariable linear regression have been used. As the results of this study indicate, the adjusted DuPont ratio and its components have more effect on investors' decisions in short term but in long the period, the effect of this ratio on herding investors' behavior are reduced. Furthermore, from the two components of adjusted DuPont ratio, profit margin has more effect on investor's decisions.
\end{abstract}

(C) 2014 Growing Science Ltd. All rights reserved.

\section{Introduction}

DuPont analysis, a common form of financial statement analysis, decomposes return on net operating assets into two different figures including profit margin and asset turnover, which measure different constructs and, thereby, incorporate various properties (Penman \& Zhang, 2003; Clement \& Tse, 2005; Romano, 2009; Amir \& Kama, 2012). Several studies indicate that a change in asset turnover is positively associated with future changes in earnings. Soliman (2008) explored the DuPont components and contributed to the literature along three ratios' dimensions. They reported that the information was useful as evidenced by associations between the DuPont components and stock returns as well as analyst predict revisions. However, he reported predictable future forecast errors and future abnormal returns implying that the information processing did not seem to be complete.

*Corresponding author. Tel: +98-9125489664

E-mail addresses: Pari.khaleghi@gmail.com (P. Khaleghi Kasbi) 
He also reported that the DuPont components represented an incremental and viable form of information about the operating characteristics of an organization.

Any financial analysis usually involves decomposing different variables into several components, emphasizing the structured hierarchy among ratios (Hwang \& Salmon, 2006). Amir et al. (2011) distinguished between unconditional persistence and conditional persistence and argued that a variable's conditional persistence could detect the magnitude of its market reaction, helping the prediction the relative magnitude of the market reaction to a ratio based on its hierarchal level in the analysis. They examined the market reaction to the DuPont ratios and reported that, while the unconditional persistence of asset turnover (ATO) was larger than that of operating profit margin (OPM), the conditional persistence of OPM was bigger than that of ATO. Thus, they forecasted and determined that the market's reaction to OPM was bigger than that to ATO. They also decomposed OPM and ATO into their second-order components and demonstrated that the market reaction depends entirely on a component's conditional persistence.

The implementation of analyst predicts as proxies for investors' earnings expectations is commonplace in most empirical research. An implicit assumption behind their implementation is that they show analysts' private information in an unbiased manner. But Trueman (1994), demonstrated that this assumption could not be necessarily true. In fact, he explained that there is a tendency for analysts to release forecasts closer to prior earnings expectations than is appropriate, given their information. In addition, he explained that herding behavior, whereby they release could predict similar to those previously announced by other analysts, even when this was not justified by their information.

Demirer and Kutan (2006) investigated the presence of herd formation in Chinese markets based on individual firm as well as sector-level data. They investigated the behavior of return dispersions during periods of large upward and downward changes in the market index. They also distinguished between the Shanghai and Shenzhen stock exchanges at the sector-level and reported that herd formation did not exist in Chinese markets. They detected that equity return dispersions were substantially higher during periods of large changes in the aggregate market index. Nevertheless, comparing return dispersions for upside and downside movements of the market, they reported that return dispersions during extreme downside movements of the market were significantly lower than those for upside movements, implying that stock returns behaved more similarly during down markets.

According to Fairfield and Yohn (2001) provided some evidence that disaggregating return on assets into asset turnover and profit margin could not necessarily provide incremental information for predicting the change in return on assets one year ahead. According to Hirshleifer et al. (2004), when cumulative net operating income outstrips cumulative free cash flow, subsequent earnings growth appears to be weak. If investors with limited attention concentrate on accounting profitability, and neglect information about cash profitability, then net operating assets, the cumulative difference between operating income and free cash flow, could obviously measure the extent in which reporting outcomes provoke over-optimism.

Hwang and Salmon (2006) presented a new non-parametric measure of herding, beta herding, based on linear factor models and implemented it to study the nature of herd behavior in the US, UK, and South Korean stock markets. Their measure was based on the cross-sectional variation of market betas. Therefore, they considered what might be called beta herding and herding towards the market index. They reported some evidence of beta herding when the market was evolving smoothly, either rising or declining, rather than when the market was in crisis. In other words, crises seemed to lead investors to seek out fundamental value rather than herd. They tested the relationship between market wide sentiment and beta herding and reported that there were separate forces at work. 
Olsen (1998) presented a comprehensive view of the origin, content, and rationale behind some behavior emerging area of study than traditional one. He discussed the traditional dominance in finance of the economic concepts of subjective expected utility and rationality. Shefrin and Statman (1994) developed a capital asset pricing theory in a market where noise traders could interact with information traders. They derived a necessary and sufficient condition for the existence of price efficiency in the presence of noise traders and investigated the effects of noise traders on price efficiency.

Tan et al. (2008) investigated herding behavior in dual-listed Chinese A-share and B-share stocks and reported some evidence of herding within both the Shanghai and Shenzhen A-share markets, which were dominated by domestic individual investors, and within both B-share markets, in which foreign institutional investors were the main participants. Herding happened in both rising and falling market conditions and herding behavior by A-share investors in the Shanghai market was more pronounced under conditions of rising markets, high trading volume, and high volatility, while no asymmetry was detected in the B-share market.

\section{The proposed study}

This paper investigates the effect of adjusted DuPont ratio and its components on investors' decisions in short and long term. The primary objective of this study is to find the effect of adjusted DuPont ratio and its components on herding behavior of investors in one and several year period. Hence, 85 corporations as the member of Tehran Stock Exchange over the period 2006-2011 are selected. In this investigation, only the shares of the firms selected that have similar fiscal calendars ending March with no change on their fiscal calendar and shares of holding firms were not selected and all information must be available. In order to recognize the herding, by market index consideration, the herded $\beta$ and in order to hypothesis validity SPSS software and multivariable linear regression have been used. The proposed study considers the following regression model,

$h_{m t}=\beta_{0}+\beta_{1} R_{N O A_{i t}}+\beta_{2} \Delta N O A_{i t}+\beta_{3} A T O_{i t}+\beta_{4} O P M_{i t}+\beta_{5} \Delta R N O A_{i t}+\beta_{6}$ Size $_{i t}+\beta_{7}$ GROWTH $_{i t}+\varepsilon_{i t}$

where $h_{m t}$ represents herding behavior, $R N O A$ denotes return on net operating assets, $\triangle N O A$ denotes changes on net operating assets, $A T O$ denotes operating assets turnover, $\triangle R N O A$ denotes changes on return on net operating assets, Size represents size of the firm, GROWTH is the change in total assets in two consecutive years. The following describes details of the calculation of each formula used in Eq. (1).

$$
\begin{aligned}
& R N O A=\frac{\text { Net profit }}{\text { Total assets }} \\
& O P M=\frac{\text { Net profit }}{\text { Net Sales }}
\end{aligned}
$$

$\triangle R N O A_{t}=R N O A_{t}-R N O A_{t-1}$

$\Delta \mathrm{NOA}=\frac{\mathrm{NOA}_{t}-\mathrm{NOA}_{\mathrm{t}-1}}{\mathrm{NOA}_{\mathrm{t}-1}}$

NOA $=$ Total operating assets - Total operating liabilities

Size $_{\text {it }}=\log$ asset

GROWTH $=($ Total assets of current year - Total assets of previous year $) /$ Total assets of previous year 
$\mathrm{h}_{\mathrm{mt}}=\frac{\beta_{\mathrm{it}}-\beta_{\mathrm{it}}^{\mathrm{b}}}{\beta_{\mathrm{it}}-1}, \beta_{\mathrm{it}}=$ regular beta and $\beta_{\mathrm{it}}^{\mathrm{b}}=$ bias beta

There are two hypotheses associated with the proposed study of this paper as follows,

1. Adjusted DoPunt and its components influence on investors' behavior in short term.

2. Among different components of Dopunt ratio, operating ratio influences more on investors' behavior in short term.

The proposed study of this paper has implemented six different regression models and Table 1 summarizes the results of our regression analysis.

\section{Table 1}

The summary of regression analysis in six different periods

\begin{tabular}{lcccccc}
\hline Period & Correlation & $\begin{array}{c}\text { Determination } \\
\text { coefficient }\end{array}$ & $\begin{array}{c}\text { Adjusted determination } \\
\text { coefficient }\end{array}$ & $\begin{array}{c}\text { Durbin- } \\
\text { Watson }\end{array}$ & F-value & Sig. \\
\hline 1 & 0.59 & 0.35 & 0.29 & 1.79 & 5.99 & 0.00 \\
2 & 0.46 & 0.28 & 0.26 & 1.80 & 6.11 & 0.00 \\
3 & 0.53 & 0.25 & 0.22 & 1.76 & 13.99 & 0.00 \\
4 & 0.53 & 0.23 & 0.21 & 1.93 & 18.21 & 0.00 \\
5 & 0.46 & 0.22 & 0.19 & 1.92 & 15.77 & 0.00 \\
6 & 0.40 & 0.16 & 0.15 & 1.87 & 13.90 & 0.00 \\
\hline
\end{tabular}

As we can observe from the results of Table 1, all components are statistically significant, which means the coefficients have positive effect on investors' behavior. The highest coefficient belongs to the first period and the lowest rate is associated with the last year. Next, we present details of the regression models in each period.

\section{The results}

In this section, we present details of our findings on applying regression model given in Eq. (1) for six different periods. Table 2 demonstrates the results of regression technique for the first year.

Table 2

The summary of regression analysis for the first year

\begin{tabular}{ccccccc}
\hline Parameter & $\beta$ & Std. dev. & Standard $\beta$ & t-value & Sig. & VIF \\
\hline Intercept & 2.03 & 2.41 & & 0.84 & 0.402 & \\
RNOA & 3.05 & 1.67 & 0.27 & 1.83 & 0.072 & 0.542 \\
$\Delta$ NOA & -1.05 & 0.48 & -0.27 & -2.19 & 0.031 & 0.741 \\
ATO & 0.10 & 0.27 & 0.04 & 0.36 & 0.723 & 0.591 \\
OPM & -1.02 & 2.13 & -0.08 & -0.48 & 0.042 & 0.131 \\
$\Delta$ RNOA $_{\mathrm{t}}$ & -3.15 & 1.13 & -0.32 & -2.79 & 0.007 & 0.531 \\
Size & -0.57 & 0.40 & 0.13 & -1.41 & 0.161 & 0.051 \\
GROWTH & 4.04 & 1.02 & 0.47 & 3.97 & 0.000 & 0.641 \\
\hline
\end{tabular}

As we can observe from the results of t-student values for different components of the regression analysis, some of them are not statistically significant. Therefore, the model is summarized into the following form,

$$
\mathrm{H}_{\mathrm{mt}}=-1.05 \Delta \mathrm{NOA}_{\mathrm{it}}-1.02 \mathrm{OPM}_{\mathrm{it}}-3.15 \Delta \mathrm{RNOA}_{\mathrm{it}}+4.04 \mathrm{GROWTH}_{\mathrm{it}}+\varepsilon_{\mathrm{it}},
$$


Similarly, we have extracted the results of regression model for other five periods and the results are summarized as follows,

$2^{\text {nd }}$ period $\quad \mathrm{H}_{\mathrm{mt}}=3.99 \mathrm{RNOA}_{\mathrm{it}}-1.91 \mathrm{OPM}_{\mathrm{it}}-1.70 \Delta \mathrm{RNOA}_{\mathrm{it}}-0.68 \mathrm{Size}_{\mathrm{it}}+2.85 \mathrm{GROWTH}_{\mathrm{it}}+\varepsilon_{\mathrm{it}}$

$3^{\text {rd }}$ period $\quad \mathrm{H}_{\mathrm{mt}}=4.73 \mathrm{RNOA}_{\mathrm{it}}-1.83 \mathrm{OPM}_{\mathrm{it}}-0.51 \mathrm{Size}_{\mathrm{it}}+2.18 \mathrm{GROWTH}_{\mathrm{it}}+\varepsilon_{\mathrm{it}}$

$4^{\text {th }}$ period

$\mathrm{H}_{\mathrm{mt}}=3.66 \mathrm{RNOA}_{\mathrm{it}}-0.87 \mathrm{OPM}_{\mathrm{it}}-0.62 \mathrm{Size}_{\mathrm{it}}+2.36 \mathrm{GROWTH}_{\mathrm{it}}+\varepsilon_{\mathrm{it}}$

$5^{\text {th }}$ period

$\mathrm{H}_{\mathrm{mt}}=4 \mathrm{RNOA}_{\mathrm{it}}-2.09 \mathrm{OPM}_{\mathrm{it}}-0.43 \mathrm{Size}_{\mathrm{it}}+2.06 \mathrm{GROWTH}_{\mathrm{it}}+\varepsilon_{\mathrm{it}}$

$6^{\text {th }}$ period

$$
\mathrm{h}_{\mathrm{mt}}=2.93 \mathrm{RNOA}_{\mathrm{it}}-0.8 \Delta \mathrm{NOA}_{\mathrm{it}}-1.24 \mathrm{OPM}_{\mathrm{it}}-0.43 \mathrm{Size}_{\mathrm{it}}+3.35 \mathrm{GROWTH}_{\mathrm{it}}+\varepsilon_{\mathrm{it}}
$$

As we can observe from the results of the regression models, as the number of years increases the coefficient of determination reduces, which confirms the first hypothesis of the survey. In addition, the value of $\beta$ for OPM is greater than the value of $\beta$ for ATO and this confirms the second hypothesis of the survey.

\section{Conclusion}

In this paper, we have presented an empirical investigation to study the effect of adjusted DuPont ratio and its components on investors' decisions in short and long term. The primary objective of this study was to determine the effect of adjusted DuPont ratio and its components on herding behavior of investors in one and several year period on firms selected from Tehran Stock Exchange. In order to recognize the herding, by market index consideration, the herded $\beta$ and in order to hypothesis validity SPSS software and multivariable linear regression have been used. As the results of this study have indicated, the adjusted DuPont ratio and its components had more impact on investors' decisions in short term but in long the period, the effect of this ratio on herding investors' behavior are reduced. Furthermore, from the two components of adjusted DuPont ratio, profit margin has more effect on investor's decisions. The results of this survey are consistent with the results reported by Amir et al. (2011) but it is inconsistent with the findings of Soliman $(2004,2008)$.

\section{Acknowledgement}

The authors would like to thank the anonymous referees for constructive comments on earlier version of this paper.

\section{References}

Amir, E., Kama, I., \& Livnat, J. (2011). Conditional versus unconditional persistence of RNOA components: implications for valuation. Review of Accounting Studies, 16(2), 302-327.

Amir, E., \& Kama, I. (2012). Conditional Persistence of Earnings Components and Accounting Anomalies. Available at SSRN 2138810.

Clement, M. B., \& Tse, S. Y. (2005). Financial analyst characteristics and herding behavior in forecasting. The Journal of finance, 60(1), 307-341.

Demirer, R., \& Kutan, A. M. (2006). Does herding behavior exist in Chinese stock markets?. Journal of international Financial markets, institutions and money, 16(2), 123-142.

Fairfield, P. M., \& Yohn, T. L. (2001). Using asset turnover and profit margin to forecast changes in profitability. Review of Accounting Studies, 6(4), 371-385.

Hirshleifer, D., Hou, K., Teoh, S. H., \& Zhang, Y. (2004). Do investors overvalue firms with bloated balance sheets?. Journal of Accounting and Economics, 38, 297-331.

Hwang, S., \& Salmon, M. (2006). Sentiment and beta herding. Behavioural Finance and Market Efficiency, Warwick Business School.

Olsen, R. A. (1998). Behavioral finance and its implications for stock-price volatility. Financial Analysts Journal, 54(2), 10-18. 
Penman, S., \& Zhang, X. (2003). Modeling sustainable earnings and P/E ratios using financial statement information. Working paper, Columbia University.

Romano, M. G. (2009). Institutional Trades and Herd Behavior in Financial Markets (No. 215). Centre for Studies in Economics and Finance (CSEF), University of Naples, Italy.

Shefrin, H., \& Statman, M. (1994). Behavioral capital asset pricing theory. Journal of Financial and Quantitative Analysis, 29(3), 323-349.

Soliman, M. (2004). Using industry-adjusted DuPont analysis to predict future profitability. Available at SSRN 456700.

Soliman, M. T. (2008). The use of DuPont analysis by market participants. The Accounting Review, 83(3), 823-853.

Tan, L., Chiang, T. C., Mason, J. R., \& Nelling, E. (2008). Herding behavior in Chinese stock markets: An examination of A and B shares. Pacific-Basin Finance Journal, 16(1), 61-77.

Trueman, B. (1994). Analyst forecasts and herding behavior. Review of financial studies, 7(1), 97124. 